\title{
IMPLEMENTATION OF MONITORING AND CONTROL PROCEDURE POLICIES IN MANGROVE ZONE OF WONOREJO DISTRICT: A CASE STUDY OF SURABAYA MAYOR REGULATION \#65 OF 2011
}

\author{
Budhiyanto ${ }^{\star}$, Budi Rianto, Viv Djanat \\ University of Hang Tuah, Surabaya, Indonesia \\ *E-mail: budhiyanto.0036@gmail.com
}

\begin{abstract}
Objective of the study is to describe and analyze the Monitoring And Control Procedure Policy Implementation In Mangrove Zone Wonorejo Distric and describing and analyzing the factors that support and hinder the successful implementation of the Mangrove Zone Monitoring and Control Procedure. This research is descriptive qualitative that examines a policy. Data analysis method uses an interactive model analysis with three procedures, namely data reduction, data presentation and conclusions / verification. In general, the research findings show that the Implementation of the Policy for the Monitoring and Control of Mangrove Areas in Wonorejo Dsitrict has been carried out in an integrated manner that includes communication aspects, resource aspects, disposition aspects, aspects of the bureaucratic structure that are clarified with policy objectives
\end{abstract}

\section{KEY WORDS}

Implementation, public policy, monitoring, control.

Mangrove forests in Indonesia are under threat from various development processes, among the main ones being rapid development in all economically vital coastal areas. Population pressure, especially in coastal areas, has resulted in changes in land use and excessive use of natural resources, mangrove forests are rapidly becoming increasingly depleted and damaged throughout the tropics (Mangrove Information Centre 2003).

Indonesia has around 3,489,140 hectares of mangroves (in 2015) or nearly $23 \%$ of the total area of the world's mangroves which is around 16,530,000 hectares, with the number of mangrove species found not less than 75 species. This condition makes Indonesia known as the country with the widest mangrove with a high level of biodiversity. Mangrove damage also occurred in the city of Surabaya, East Java Province, according to available data that $40 \%$ of the total area of mangrove forests in the city of Surabaya has been damaged.

Mangrove forests are very important for the lives of living creatures around them, both for humans and animals. Mangroves function as a deterrent to abrasion and erosion of the beach by sea water. Mangrove forests are also home to various kinds of flora and fauna. One area that has a well-known mangrove habitat in Surabaya is in Wonorejo District, the area is located on the edge of the Madura Strait which is relatively narrow, but has a very important role as a Pamurbaya buffer from the threat of sea abrasion. The mangrove area is a coastal green lane that has ecological and socio-economic functions. With the increasing number of residents and the demands of higher needs, it has an impact on uncontrolled exploitation of the use of the area and the results of mangrove forests in the city of Surabaya which results in damage and decreasing of existing land or mangrove areas.

Therefore efforts to supervise and control mangrove areas must be carried out and supported by all Stake Holders and the community, so that the sustainability of mangrove forests will always be maintained and will have a positive impact on the surrounding community. The form of protection against mangroves in order to maintain its sustainability is directed by the existence of a policy of monitoring and controlling mangrove areas in the city of Surabaya. Referring to the Mayor's Regulation Number 65 of 2011 that the protection and preservation of mangroves leads to the form of procedures for monitoring and controlling mangrove areas in the city of Surabaya which include aspects of communication, resource aspects, disposition aspects, aspects of bureaucratic structures. 


\section{THEORETICAL FRAMEWORK AND HYPOTHESIS}

Conceptual Definition of Public Policy Implementation. Public policy actually has become a social reality since humans realize that they have the same life goals in addition to the variety of interests that exist. The basic definition of public policy is the realization of the desire of social scholars to solve social problems in the field (close the gap between knowledge and policy) (Parsons, 2005). Therefore public policy is seen as a guideline or guide chosen by decision makers to control certain aspects of social problems (Finsterbuch and Motz, 1990).

Policy implementation is an effort to apply the results of the formulation that has been carried out. In implementing policies, the efforts that are trying to find are patterns and trying to achieve large or small changes as previously decided. Implementation is essentially an effort to try to answer the question of what should happen after a program is implemented.

Van Meter and Van Horn (Wahab, 1997) asserted that the implementation process is "those actions by public or private individuals groups that are directed towards the objectives of forthcoming prior decisions". Implementation is an effort to achieve certain goals with certain means and in a certain time sequence.

According to Van Meter and Van Horn (Subarsono, 2005), there are six variables that affect implementation performance, that is:

- Policy standards and targets. Policy standards and targets must be clear and measurable so that they can be realized;

- Resources. Policy implementation needs to support resources both human resources and non-human resources;

- Relationships between Organizations. In many programs, the implementation of a program needs support and coordination with other institutions;

- Characteristics of implementing agents. What is meant by the characteristics of implementing agents includes the structure of the bureaucracy, norms, and patterns of relations that occur in the bureaucracy, all of which will affect the implementation of a program;

- Social, political and economic conditions. This variable includes environmental economic resources that can support the success of policy implementation;

- Disposition of the implementor. The implementor's disposition includes three important things, namely: the implementor's response to the policy, which will influence the way to implement the policy. and the intensity of the disposition of the implementor, namely the value preferences possessed by the implementor.

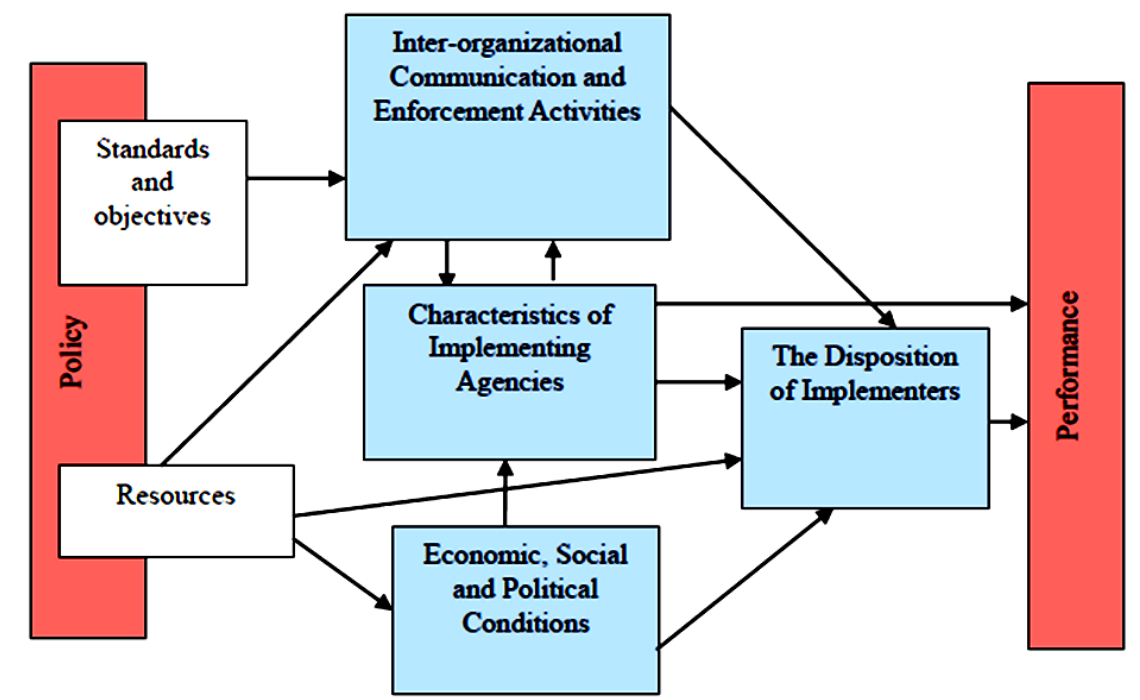

Figure 1 - Policy Implementation According to Van Meter and Van Horn (Source: Van Meter and Van Horn (Subarsono, 2005) 
Mangrove Area Monitoring and Control Policy. Sondang (2005) defines monitoring as a process of observation of the implementation of all organizational activities to ensure that all work being carried out is carried out in accordance with a predetermined plan. Supervision is every effort and action in order to find out the extent to which tasks are carried out according to the provisions and objectives to be achieved.

Control is a very important part of the management function so that it must get attention so that it can be implemented properly. According to Bateman \& Snell (2008) control is monitoring the progress of the organization or work unit towards the objectives and then taking corrective actions if needed.

According Surabaya Mayor Regulation Number 65 of 2011 concerning Procedures for Supervision and Control of Mangrove Areas, mangroves are a collection of plants dicotiledoneae and / or monocotyladenae consisting of plant species that have taxonomic relationships to unrelated families but have similar morphological and physiological adaptations to habitats affected by tides.

The policy of monitoring and controlling mangrove areas is a policy made to protect and preserve mangrove areas. The policy of mobitoring and controlling mangrove areas in Surabaya is contained in the Surabaya Mayor Regulation Number 65 of 2011. The Mayor's Regulation adopts various policies made by the central government in determining the various regulations article by article. This policy is very good because the existence of this policy can protect and preserve mangroves both in Wonorejo and throughout the mangrove areas in Surabaya.

Mangrove or mangal is a general designation used to describe a variety of tropical coastal communities dominated by several species of distinctive trees or shrubs that have the ability to grow in salty waters (Nybakken, 1988). Mangroves are one of the least arising soil plants that are resistant to open sea salinity (Odum, 1993). Although not the same as the term mangrove, many people or lay residents call mangroves as mangroves or briefly called mangroves.

Characteristics of mangrove habitat are (1) generally grows in intertidal areas whose soil types are muddy, or sandy, (2) periodically inundated areas of the sea both daily and which are only flooded during full moon tides. Inundation frequency determines the composition of mangrove vegetation, (3) receives sufficient fresh water supply from land, (4) is protected from large waves and strong tidal currents.

Mangroves are a tropical and sub-tropical coastal vegetation community, which is dominated by several types of trees (such as Avicennia, Sonneratia, Rhizophora, Bruguiera, Ceriops, Lumnitzera, Exoecaria, Xylocarpus, Aegiceras, Scyphyphora and Nypa) that can grow and develop in coastal tidal areas muddy (Bengen, 2004b). Bengen (2000) states that mangrove ecosystems have functions, among others: (1) as a protective beach from the onslaught of waves, currents and wind, (2) as a shelter, spawning or breeding and fostering areas of various types of biota (3) as producers of materials highly productive organics (detritus), (4) as a source of fuel industry raw materials, (5) suppliers of fish larvae, shrimp and other marine biota, and (6) tourism places.

Framework of Thinking and Hypothesis. Policy is a system in which there are elements that are interconnected and influence. Public policy is a series of choices that are more or less interconnected (including decisions not to act) made by government agencies and officials. As a guide, public policy provides direction for future behavior as well as a unified direction for a number of programs and projects that require large and small decisions. The direction of this action is generated through the selection process by policy makers from a number of alternative choices available so that this action is deliberate action.

Islamy (2001) explains that the first step that policy makers make is to identify the problem to be solved, then make the clearest formulation of the problem. The main problem that occurs is that damage to coastal areas, mainly mangrove forests, is caused by human activities both in small and large scale, both directly and indirectly and this damage greatly affects the follow-up effects experienced by the region. The activities can be in the form of illegal logging, opening of farms, opening of recreational facilities, waste disposal, residential areas, and industry. 
The policy of monitoring and controlling mangrove areas on the East Coast and North Coast of Surabaya is stated in Surabaya Mayor Regulation Number 65 of 2011 concerning "Procedures for Monitoring and Control of Mangrove Areas in Surabaya City Region" Implementation is a very important aspect in the entire policy process due to public policies that have made will be useful if implemented. A policy program must be implemented so that it has the desired impact or goal. Implementation is seen as a process of interaction between a set of goals and actions that are capable of achieving policy objectives. Where in the implementation of policies, actors, organizations, procedures and techniques are used together and simultaneously.

According Van Meter and Van Horn (Subarsono, 2005) there are five variables that influence policy implementation, namely (1) policy standards and targets; (2) resources; (3) inter-organizational communication and activity strengthening; (4) characteristics of implementing agents; and (5) social, economic and political conditions.

Based on the combination and elaboration of variables that affect implementation performance, namely Policy Size and Objectives, Resources, Organizational Communication, Implementing Attitudes, Social, Political and Economic Environment Conditions are expected to improve the procedures for controlling and controlling mangrove areas in Wonorejo District, Surabaya City.

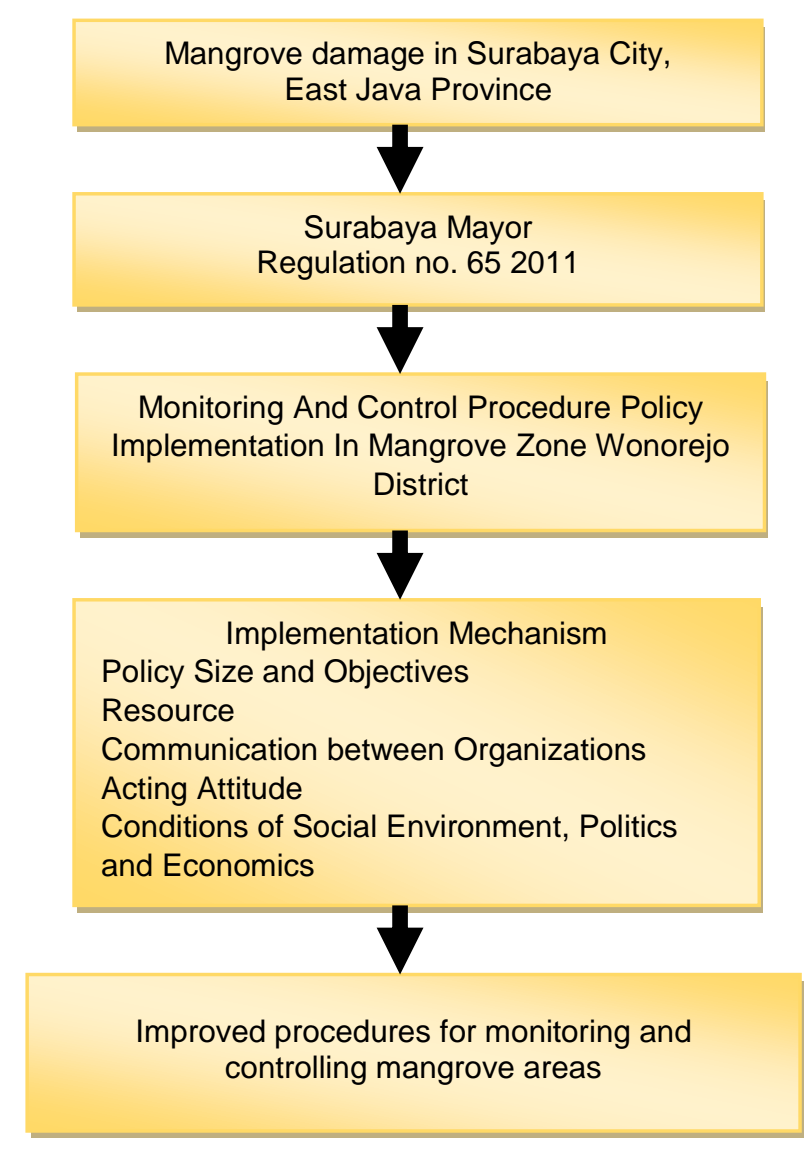

Hypotheses. Based on the framework, the hypotheses are as follows: Monitoring And Control Procedure Policy Implementation In Mangrove Zone Wonorejo Distric will be useful if the mechanism is integrated, which includes aspects of size and policy objectives, communication aspects, resource aspects, disposition aspects, aspects of bureaucratic structure, implementers' attitudes that are aligned with the policies of Surabaya Mayor Regulation no. 65 of 2011.

Subject of the Study. The subjects of this study were the Mangrove Area of Surabaya City in Wonorejo District. 
Respondents were related officials / personnel from the Head of the Surabaya City Food and Agriculture Resilience Service, Head of the Surabaya City Environment Office, Wonorejo Districr Head, several Chairmen of Farmers' Groups, Members of NGOs and NonGovernmental Organizations. Data collection techniques used in this study were through interviews, observation, and documentation.

The object of the research is the policy of monitoring and controlling the mangrove area which includes aspects of size and policy objectives, aspects of communication, aspects of resources, aspects of disposition, aspects of bureaucratic structure, attitude of the implementer. These objects become research variables and analyzed using interactive model analysis with three procedures, namely data reduction, data presentation and conclusion / verification.

\section{METHODS OF RESEARCH}

This study applies a qualitative method that is descriptive qualitative by explaining that a policy is said to be successful if the policy implemented has the desired impact. In this study qualitative methods were used to explain the problems in the mobitoring and control procedures of the Surabaya City mangrove area in Wonorejo District. This method is used to explain the purpose and objectives of the study where some of the questions that arise as well as data obtained, such as monitoring and control procedures, Factors that influence the implementation of monitoring and control procedures for mangrove areas in Wonorejo District, Surabaya.

The unit of analysis is the Size and Purpose of the Policy, Resources, Communication between Organizations, Implementing Attitudes, Conditions of the Social, Political and Economic Environment related to the supervision and control procedures of the Surabaya mangrove area in Wonorejo Village. Data analysis method uses data analysis that has been developed by Miles and Huberman (Emzir, 2010), using ineractive model analysis with three procedures, namely data reduction by conducting a simplification process of data from various sources and various methods to determine themes and organize data according to research focus which includes the procedure of mobitoring and control of the mangrove area of Surabaya City in Wonorejo District. Submission of data is done in a way by using tables and figures related to the supervision and control procedures of the Surabaya mangrove area in Wonorejo District. Conclusions / verification by means of any conclusions will always continue to be verified during the research that involves the interpretation of the researcher.

\section{RESULTS AND DISCUSSION}

Monitoring and Control of the Mangrove Area in Surabaya Wonorejo Village has the size and purpose as stipulated in the Procedure for Mobitoring and Control of the Mangrove Area in the Surabaya City area, which begins with socialization, community empowerment, monitoring and evaluation, investigation and ending with reporting. The socialization was carried out by the Mangrove Zone Monitoring and Control Team with the aim of providing understanding to the public about the laws and regulations relating to the mangrove area. Dissemination is carried out periodically and / or as needed by face to face and / or through mass media.

Community Empowerment by the Mangrove Zone Monitoring and Control Team aims to provide knowledge to the community in efforts to preserve and manage natural resources in the mangrove area, provide knowledge and skills to the community in utilizing mangrove as an effort to improve community welfare.

Monitoring and Evaluation by the Mangrove Zone Monitoring and Control Team aims to monitor and provide an assessment of the condition of the mangrove area as a consideration for decision making by the Mayor and as a basis for taking action in the field. The investigation was carried out by Investigators of Civil Servants in the Surabaya City Government who were authorized to take action to investigate violations of regional regulations that occurred in the mangrove area. In the event of a violation of Law Number 5 
of 1990 concerning Conservation of Natural Resources and Ecosystems or Law Number 27 of 2007 concerning Management of Coastal Areas and Small Islands or other Laws. Reporting by the Chairperson of the Mangrove Zone Monitoring and Control Team submits a report to the Mayor on a regular basis every month and incidentally as needed.

Resources are one of the important factors in the process of implementing or implementing a program or policy, where without the support of adequate resources, whether in the form of the amount or ability or expertise of the program implementers or the implementation policies of a program will not achieve its objectives. Availability of resources in implementing a program or policy is one factor that must always be considered, if the policy is implemented as planned.

Food and Agriculture Resilience Service has 53 employees and has a background and level of education and groups that vary from group II to 7 people, group III as many as 37 people, and group IV as many as 9 people, with details 53 men and 21 women and based on the number and composition of his rank, human resources are sufficient.

Communication is something that really determines the success of achieving the objectives of public policy implementation. Communication involves the process of delivering information or transmission, the clarity of the information and the consistency of the information conveyed Knowledge of the things they do can work if the communication goes well, so that any policy decisions and implementation regulations must be communicated to the appropriate personnel department.

Sosalisai Mayor Regulations are not found in the form of publications in the form of books, brochures, and digital publications, the existing publications are only those of Perwali, thus the relations between organizations especially those in the team are limited to normative relations as government agencies.

The structure of the bureaucracy has a potential and real relationship with what they have in carrying out policies. Complex policies require the cooperation of many people. Elements that might influence an organization in policy implementation include the level of hierarchical supervision of sub unit decisions and processes in the implementing agency.

Characteristics of the implementing agency Policy procedures for controlling and controlling mangrove areas in this line of the Surabaya City Food and Agriculture Resilience Agency, Surabaya City Marine and Fisheries Service have good bureaucratic structures, characteristics, norms and coordination, potential and tangible in carrying out procedure policies supervision and control of mangrove areas.

Head of the Surabaya Food and Agriculture Resilience Office as Chair of the Mangrove Zone Monitoring and Control Team in Surabaya City and Secretary of the Surabaya Agriculture Office as Secretary. While the Head of the Environment Agency, Head of the Community Empowerment and Family Planning Agency, Head of the Cipta Karya and Spatial Planning Office, Head of the Civil Service Police Unit, Local Sub-District Head as Member, Local Village Head, and SKPD Surabaya City served as members.

Surabaya City Marine and Fisheries Agency which also has authority on conservation areas of coastal areas and small islands excluding members in the Major Regulations.

One of the factors that influence the effectiveness of policy implementation is the attitude of the implementor or apparatus. If the apparatus agrees with the parts of the contents of the policy to be executed, they will carry out happily, but if their views differ from those of the policy makers, the implementation process will experience many problems and not achieve the programs that have been made. Trends in behavior or characteristics of policy implementers play an important role in realizing the implementation of policies that are in accordance with the goals or objectives. Important characteristics that must be possessed by implementing policies such as honesty and high commitment. Honesty directs the implementor to stay in the program that has been outlined, while the high commitment of the implementers of the policy will make them always enthusiastic in carrying out their duties, authority, functions, and responsibilities in accordance with established regulations.

The level of commitment and honesty of the apparatus in policy implementation is the most important thing from the Effect of Disposition or Tendencies, because in implementing a policy it can affect the desire and willingness to implement a policy, the desire and 
willingness of an apparatus can be seen from the knowledge of a policy implemented, understanding and deepening of a policy and acceptance of the apparatus in the policy whether accepting, rejecting or neutral.

Implementation Policy procedures for monitoring and controlling mangrove areas are accompanied by high commitment to achieve the targets set by always improving service quality. Commitments from implementers to policies or programs that must be implemented because each policy requires implementers who have strong desires and high commitment to be able to achieve the stated policy objectives in accordance with the procedure.

The economic potential of the mangrove ecosystem comes from three sources, namely flora, fauna, and environmental services of the mangrove ecosystem. Mangrove ecosystems provide various types of products and services that are useful for supporting the living needs of coastal residents and various economic activities, both locally, regionally and nationally as well as supporting the living systems of communities around the forest. All these mangrove functions will continue if the existence of a mangrove ecosystem can be maintained and the use of its resources is based on the principles of sustainability. This means that mangroves act as renewable resources and support the living system if all the ecological processes that occur within the mangrove ecosystem take place without interruption.

Economically involving the community in the management and supervision system also provides benefits for both parties, both the communities around the mangrove area which are generally relatively poor and also the government which acts as the managing institution. Thus the strategy that involves community participation in efforts to manage the mangrove ecosystem in addition to achieving the objectives of Mangrove forest conservation must also be able to overcome the socio-economic problems of the communities around the area.

\section{DISCUSSION OF RESULTS}

Monitoring And Control Procedure Policy Implementation In Mangrove Zone Wonorejo Distric has not been fully implemented as mandated in Surabaya Mayor Regulation Number 65 of 2011. Implementation of the Surabaya Mayor Regulation based on the aspects contained in it is not yet effective and optimal and according to the expected target. Among the integrated stages describing the forms of inequality during the process of implementing the Surabaya Mayor Regulations were carried out. In addition to supporting factors that can still be used as a pillar of this policy can survive, there are also several inhibiting factors in it, both internal and external.

Based on the Aspect of Size and Policy objectives, the implementation of the policies mentioned by Van Meter and Van Horn is very integrated with the policy conditions of the Surabya City Mayor, namely the implementation of these policies by various agencies such as the Surabaya City Agriculture Agency, Surabaya City Environment Agency, Cipta Karya and Spatial Planning Surabaya City, Surabaya City Civil Service Police Unit, Rungkut SubDistrict Head, Wonorejo Urban Village Head, and Wonorejo Community. Here all the monitoring and control team of mangroves do their best to achieve policy objectives by not leaving the main tasks and functions of each agency, besides that as a guideline also in supervising and controlling mangrove areas in Wonorejo.

Based on the Communication Aspect that communication carried out in the policy of mobitoring and controlling mangrove areas is carried out through two phases, namely internal communication carried out through delegation between implementers and all staff understanding the Program through policies that have been made in writing. External communication with the community, carried out by means of program socialization carried out by officials to the community, as well as increasing cooperation with vertical agencies. According to Van Meter and Van Horn (1975) consistency of the information conveyed is needed in order to avoid confusion between the parties involved in its implementation. Likewise with the implementation of policies on procedures for controlling and controlling mangrove areas, information consistency is highly demanded, but if there is a change because of seeing the condition of the community, information that circulates in the community automatically also changes. 
Based on the Resource Aspect in the policy procedures for monitoring and controlling mangrove areas, both in quality and quantity. Food and Agriculture Resilience Service Data has 53 employees and has a background and level of education and groups that vary from group II to 7 people, group III as many as 37 people, and group IV as many as 9 people, with details 53 men and 21 women and based on the number and composition of its rank, human resources are sufficient to implement the policy. This finding is in accordance with the theory put forward by Van Meter and Van Horn (1975) which states that the number and quality of adequate implementers have a very positive impact on the implementation of policies.

One of the factors that influence the effectiveness of policy implementation is the attitude of the implementor. If the implementor agrees with the contents of the policy then they will carry out happily but if their views differ from those of the policy maker then the implementation process will experience many problems. In addition, support from implementing officials is needed to achieve the program objectives. The manifestation of this leadership support includes placing policies as program priorities and providing sufficient funds to provide incentives for program implementers so that they support and work in total in implementing policies / programs.

Disposition is an aspect related to the attitude and support of the implementers of the program or policy. Attitudes and support are very important in the implementation process, because similarity of views on what is done together will facilitate the achievement of goals. If the implementers or implementors of the policy are divided in terms of attitudes and support, what will be achieved from a policy will not be achieved effectively and efficiently, because it will face many obstacles and obstacles from the implementing officers of the policy itself, where the implementation of programs or policies sometimes problematic if the executor involved in it cannot run the program or policy properly. If the implementer has a good disposition, then he will implement the program or policy well as cooled by policy makers, whereas if the implementer has a different attitude from the policy maker, then the implementation process of a program or policy will also not be effective and efficient.

The attitude of the policy implementers with policy makers, the findings of the research shows a positive attitude and supports the implementation of the procedures for monitoring and controlling the mangrove area, in terms of the human resource capacity the implementers of this policy have the willingness to accept the policy and readiness to carry out tasks in accordance with the Letter of Assignment and available procedures. Based on the theory of Van Meter and Van Horn (1975) the appointment and selection of program implementing personnel must be the right people and have dedication to the tasks carried out. So that the implementation of a program can run effectively.

According Van Meter and Van Horn (1975), the variables that influence the implementation of public policy are bureaucratic structures. Even though the sources for implementing a policy are available or policy implementers know what should be done and have the desire to implement a policy, it is likely that the policy cannot be implemented or realized because of weaknesses in the bureaucratic structure.

Bureaucratic structure is a characteristic, norms and patterns of relationships that occur repeatedly in executive bodies that have both potential and real relationships with what they have in carrying out policies. Complex policies require the cooperation of many people. Elements that might influence an organization in policy implementation include the level of hierarchical supervision of sub unit decisions and processes in the implementing agency.

In the policy of monitoring and controlling mangrove areas the Food and Agriculture Resilience Agency and the Surabaya City Marine and Fisheries Service already have standard operating procedures regarding a series of written instructions standardized in implementing policies with reference to SPOPP and Surabaya Mayor Regulation no. 65 of 2011.

Based on the results of the study, it can be seen that the form of coordination and cooperation between the parties involved in the implementation of the policy of controlling and controlling the mangrove area is going well, this can be seen with the alertness of the implementers in resolving various problems that arise as seen from the tasks and functions they have. 


\section{CONCLUSION}

Based on observations and interviews, note that Policy Size and Objectives. The Supervision and Control Team has not carried out its duties to the fullest in accordance with Surabaya Mayor Regulation Number 65 of 2011, and has not made Standard Operating Procedure (SOP) as the basis for carrying out its duties. The Monitoring and Control Team already has adequate human, material and financial resources.

The Oversight and Control Team has good cooperative relations with government and private agencies, but does not socialize Perwali to the Team because it is considered to have known and socialized only in the form of posting on the Website. The Monitoring and Control Team lacks coordination between Team members and there is overlapping of authority in carrying out tasks. The Monitoring and Control Team knows the tasks that must be carried out, but has not yet committed to implementing them properly. With the stipulation of Wonorejo Urban Village as a mangrove ecotourism area affecting the economic conditions of the community.

Factors that hinder the implementation of the policy include socialization, the location of the village Wonorejo relatively far from the city of Surabaya, so that the supervision and control procedures have not been implemented maximally. Community Empowerment, community empowerment activities have not been carried out by the Supervision and Control Team optimally, but it is often carried out by universities, NGOs, the Indonesian National Army, especially the Navy and other agencies. Monitoring and Evaluation, there is no direct monitoring and evaluation carried out by the Monitoring and Control Team. Investigation, the absence of law enforcement actions related to the existence of violations. Reporting, the activities reported are activities carried out by other parties.

Factors that support the implementation of policies include socialization; many other parties carry out socialization (Higher Education, Non-Governmental Organizations, Indonesian Navy, Private Sector etc). Community Empowerment, there are activities carried out by other parties in collaboration with the city government in community empowerment. Monitoring and Evaluation, there is concern from other parties in the management of mangrove areas. Investigation, the concern of other parties in monitoring the existence of mangroves is very helpful. Reporting, reporting on conditions and activities in the mangrove area is well reported.

\section{RECOMMENDATIONS}

Taking into the results of the research concluded above and looking at several factors that support and hinder the implementation of the policy itself, the authors formulated a number of recommendations and recommendations so that the implementation of procedures for monitoring and controlling mangrove areas is more efficient, including the need to appoint the Head of Maritime and Fisheries Services as Team Leader Monitoring and Control of the Mangrove Area and placing the Head of the Food and Agriculture Security Service as Deputy Chairperson.

The Chair of the Supervision and Control Team must rotate PNS / ASN by placing qualified personnel in their fields. Chairman of the Supervision and Control Team conducts socialization of Perwali no. 65 of 2011 to the public, government and private institutions, educational institutions, NGOs etc. The Supervision and Control Team in order to compile an SOP (Standard Operating Procedure) and work program as the basis for carrying out their duties. The Mayor of Surabaya always supervises the implementation of the Mangrove Zone Monitoring and Control Procedure.

\section{REFERENCES}

1. Bateman, Thomas S., Snell Scott A., 2008, Manajemen: Kepemimpinan and Kolaborasi dalam Dunia yang Kompetitif, Alih Bahasa Chriswan Sungkono and Ali Akbar Yulianto, Salemba Empat, Jakarta. 
2. Emzir. 2010. Metode Penelitian Kualitatif. Analisis Data. Rajawali Pers. PT. Grafindo Persada.Jakarta.

3. Finsterbusch, K. \& Partridge, W.L.. 1990. The development anthropologicla approach. Oxford: Westview.

4. Islamy, M. Irfan,2001, Prinsip-prinsip Perumusan Kebijakan Negara, Jakarta, Bumi Aksara.

5. Nybakken, 1988 Nybakken, J.W. 1988. Biologi Laut: Suatu Tinjauan Ekologis (terjemahan) GramediaPustaka Utama. Jakarta.

6. Odum, E.P. 1993. Dasar-dasar Ekologi. Diterjemahkan oleh T. Samingan. Gajah Mada University press. Yogyakarta.

7. Parsons, Wayne. 2005. Public Policy Pengantar Teori and Praktik Analisis Kebijakan. Jakarta: Prenada Media.

8. Siagian, Sondang. 2005. Patologi Birokrasi Analisis Identifikasi and terapinya. Jakarta; Ghalia Indonesia.

9. Subarsono, A.G. 2005. Analisis Kebijakan Publik Konsep, Teori and Aplikasi. Yogyakarta: Pustaka Pelajar

10. Carl Van Horn and Donal Van Meter. 1975, Model-model dalam Kebijakan Implementasi, Yogyakarta.

11. Wahab, Solichin A. 1997. Analisa Kebijakan: Dari Formulasi ke Implementasi Kebijakan Negara, Jakarta: Bumi Aksara. 